\title{
FILOZOFIA I RELIGIA W UJĘCIU MAINE DE BIRANA
}

W 1984 roku minęło 160 lat od śmierci francuskiego filozofa Maine de Birana. Jest on uważany za twórcę kierunku filozoficznego określanego mianem spirytualizmu ${ }^{1}$. Żył w latach 1766 - 1824, a więc w okresie oświecenia, zarazem w trudnych czasach Wielkiej Rewolucji Francuskiej. Wykształconym filozofem nie był. Filozofię traktował jako uboczne zajęcie, poświęcając najwięcej czasu polityce. Mimo to jednak jest znany nie jako polityk, ale właśnie jako filozof. Czytał bardzo dużo. Z ulubionych jego filozofów starożytnych wymienić należy przede wszystkim Platona i Ksenofonta. Chętnie też studiował dzieła Rousseau, Kartezjusza, Pascala, Leibniza i Kanta. Własne przemyślenia Maine de Birana nie stanowią zwartego systemu filozoficznego ${ }^{2}$. Jego ulubionym tematem refleksji filozoficznej jest — jak sam się wyraża — „studium człowieka”. W ramach tego właśnie „studium człowieka” pojawia się w twórczości Maine de Birana problem wzajemnych relacji pomiędzy filozofią a religią. Prezentowany artykuł stanowi próbę syntezy tego zagadnienia.

\section{FILOZOFIA - PRZEDMIOT I METODA}

W dziele zatytułowanym: Défense de la philosophie Maine de Biran pisze: „[...] człowiek zaczyna uprawiać filozofię wtedy, gdy się zastanawia, gdy korzysta ze swego rozumu, ze wszystkich władz intuicyjnych" (O. XII 54). Zastanawiać się to przede wszystkim stawiać pytania i szukać na nie odpowiedzi ${ }^{3}$. Co wszakże ma stanowić przedmiot tej filozoficznej refleksji: cała otaczająca nas rzeczywistość, przyroda, świat - jednym słowem wszystko to, co istnieje? Nie. Przedmiotem filozoficznej refleksji jest człowiek, a dokładniej — czło-

* W tekście artykulu zastosowano następujące skróty tytułów dzieł Maine de Birana (cyfra rzymska oznacza tom, lacińska - stronę):

O. - Oeuvres de Main e de Biran, t. I-XIV, Paris 1920-1949.

J. - M. de B ir a n, Journal, t. I-III, Neuchatel 1954-1957.

${ }^{1}$ Por.: Wł. Ta t a rk i e w i c z, Historia filozofii, t. 2, Warszawa 1949, s. 307; F. J. Th on n a rd, Précis d'histoire de la philosophie, Tournai 1963, s. 688. s. 419 .

2 Por. G. Le Roy, L'experience de l'éffort et de la grâce chez Maine de Biran, Paris 1937,

${ }^{3}$ Main de Biran posługuje się terminem „raison” w znaczeniu intelektu, władzy bezpośredniego ujęcia rzeczy. Jest to więc rodzaj intuicji o podbudowie intelektualnej. Na oznaczenie tego typu poznania posługuje się też często wyrażeniem: „faculté intuitive”, względnie — „facultés intuitives". 
wiek i moralność, czyli człowiek jako istota moralna. Zdaniem Maine de Birana „w studium nad człowiekiem i naturą moralności należy szukać początków filozofii” (O. XII 56). A zatem człowiek i jego ścisły związek z moralnością stanowi „od początku” przedmiot filozoficznych poszukiwań. Dlatego tak określonego przedmiotu filozofii nie można dowolnie zmieniać. Filozof winien pozostać wiernym tak rozumianej filozofii. Wobec tego termin „filozofia” stosować należy wyłącznie do studium człowieka i moralności. Natomiast wiedzy o przyrodzie nie można uważać za filozofię (O. XII 116).

Wczytując się w powyższe sformułowania Maine de Birana łatwo zauważyć, że przypominają one Sokratesowską wizję filozofii. To przecież Sokrates oddzielił wiedzę o człowieku i moralności od wszystkich innych zainteresowań i nazwał ją filozofią. Przyznaje to Maine de Biran pisząc: „Przed Sokratesem [...] byli politycy, mówcy, matematycy, muzycy nie było jednak filozofów" (O. XII 75). Słusznie przeto Sokrates uchodzi za ojca filozofii, której kiedyś reformatorem będzie Kartezjusz. Surowo ocenił Maine de Biran poprzedników Sokratesa, także samego Arystotelesa mówiąc, że Sokrates zaliczyłby go prawdopodobnie do grona sofistów, którzy odznaczali się rozległą wiedzą, jak właśnie Stagiryta. Maine de Biran nie może wybaczyć Arystotelesowi tego, że „zapomniał on, żeby tak powiedzieć, o filozofii w ujęciu Sokratesowskim, przesuwając punkt zainteresowań z człowieka i moralności na przedmioty fizyczne" (O. XII 90).

Swoją filozofię Maine de Biran uprawial, posługując się również metodą Sokratesowską, która stanowi pewien rodzaj intuicji intelektualnej. Tak właśnie postępował Sokrates, który „szukał prawdy w sobie samym [...] i znalazł prawdy pierwsze" (O. XII 75). Były to prawdy dotyczące człowieka i moralności. I tą tylko drogą winna odtąd kroczyć filozofia. Istotnie Sokratesowską koncepcję filozofii przejęli jego dwaj uczniowie: Ksenofont i Platon. W czasach nowożytnych filozofia Sokratesowska odżyła - zdaniem Birana - w systemach Kartezjusza, Hume'a, Locke'a, Reida, Leibniza, Kanta. Istnieją pomiędzy tymi systemami niewątpliwe różnice. Łączy je jednak sprawa istotna, tj. przedmiot filozofii: człowiek i moralność. $Z$ tego względu ,pomimo różnorodności systemów filozoficznych, istnieje tylko jedna, prawdziwa filozofia o charakterze intelektualno-moralnym" (O. XII 100). Owa jedna i prawdziwa filozofia jest możliwa dlatego, że poszczególni filozofowie, pomimo dzielących ich różnic, podejmują wciąż na nowo studium człowieka. Co jednak stanowi o różnicy istniejącej między poszczególnymi kierunkami filozoficznymi? Zdaniem de Birana różnicę powodują zagadnienia, które chociaż są przedmiotem rozważań filozofów, to jednak do filozofii nie należą. I dlatego marzy mu się sytuacja, w której z poszczególnych systemów usunie się zagadnienia nie będące bezpośrednio związane z człowiekiem i moralnością. Ulegnie wtedy gruntownej przemianie obraz historii filozofii. Maine de Biran pisze: „historia filozofii winna i może być z wielką korzyścią skrócona i uproszczona" (O. XII 58). Jest 
to bez wątpienia wielki program przebudowy historii filozofii. Powstaje jednak pytanie, czy jest to program wykonalny a nade wszystko, czy taka zmiana jest naprawdę konieczna?

\section{FILOZOFIA I RELIGIA NA PŁASZCZYŹNIE TEORETYCZNEJ}

Ludzki umysł — zdaniem Maine de Birana — posiada skłonność do przyjmowania postawy skrajnej. Stajemy wtedy wobec alternatywy: rozum albo wiara. I wtedy jesteśmy skłonni „slepo we wszystko wierzyć”, nawet w to, co rozum ludzki może poznać (O. XII 107). Jest też sytuacja odwrotna, gdy mianowicie będzie się odrzucać wszelką wiarę, ponieważ nie można jej udowodnić. Inaczej mówiąc postawa kształtuje się od skrajnego racjonalizmu lub ślepej wiary. Są to ujęcia skrajne a przez to „przeciwne prawom ludzkiego ducha” (O.XII 106). Tymczasem nie można szukać odpowiedzi dla wszystkich zagadnień wyłącznie w dziedzinie wiary. „Pomiędzy tymi dwoma skrajnościami pisze Biran - znajduje się prawdziwa filozofia" (jw.). To ona właśnie poucza nas, jaka jest rola wiary a jaka rozumu; inaczej mówiąc, jaka jest rola religii i filozofii w szukaniu prawdy o człowieku i moralności. Postawa taka wymaga naturalnie rozgraniczenia dziedziny filozofii i religii. To rozgraniczenie jest również dziełem prawdziwej filozofii. Ponieważ „prawdziwa filozofia umie wyznaczyć granice tak sobie samej jak i uszanować granice wiary (O. XII 107), Maine de Biran postawił zatem dwa postulaty: po pierwsze, należy przyjąć jako fakt istnienie filozofii i religii; po drugie, obie te dziedziny winny wzajemnie szanować swoje kompetencje. Dzięki temu uniknie się konfliktu, jaki pomiędzy tymi dwoma dziedzinami miał miejsce w historii. Konflikt taki istniał właśnie w czasach oświecenia. Rozum był wówczas jedyną miarą prawdy. Religia zaś o tyle była do przyjęcia, o ile była zgodna $\mathrm{z}$ rozumem. W takiej sytuacji nie było miejsca dla religii objawionej. Maine de Biran proponuje zatem rozwiązanie, które było przeciwne panującym wówczas tendencjom, szczególnie we Francji. Cel zabiegów Maine de Birana jest przeto jasny: należy unikać konfliktu pomiędzy filozofią a religią. Jest to zupełnie możliwe i stanowi tylko część relacji, jakie istnieją między religią a filozofią. Można to nazwać aspektem negatywnym, ponieważ chodzi o unikanie konfliktu.

Istnieje także część pozytywna wzajemnych relacji, którą jest wzajemna współpraca pomiędzy filozofią i religią. Czym i w jaki sposób uzasadnić tę współpracę? Najpierw — zdaniem de Birana - filozofia i religia posiadają swe wspólne źródło. Pojmuje on bowiem filozofię, jak i religię, jako dwa sposoby — lub raczej jako dwie drogi — którymi do nas dociera prawda. Źródłem owej prawdy jest Bóg. W tym też znaczeniu można rozumieć jego twierdzenie, że „filozofia w ten sposób rozumiana... nie może różnić się od religii [...] ani źródłem, z którego wypływa a którym z konieczności jest Bóg, ani też podstawą 
na której się opiera: jedna i druga pochodzą od Boga" (O.XII 97). Tę samą myśl Biran rozwija jeszcze w inny sposób. Uważa on mianowicie, że religia i filozofia posiadają względem człowieka podobną rolę do spełnienia. Na czym ta wspólna rola polega? De Biran pisze następująco: „Możemy wyróżnić dwa rodzaje objawienia: pierwszy rodzaj to objawienie wiary lub powaga religii [...] drugi rodzaj to objawienie płynące z rozumu lub inaczej powaga oczywistości" (O. XII 65). Gdzie indziej jeszcze bardziej precyzuje: „Istnieją dwa rodzaje objawienia: zewnętrzne $w$ formie ustnej lub pisanej i wewnętrzne, objawienie świadomości" (O. XII 52). Łącząc obie te wypowiedzi otrzymamy następujący podział: objawienie religijne dla Birana jest to objawienie religii chrześcijańskiej składające się z Tradycji ustnej i Pisma świętego, oraz objawienie rozumu określane przez niego terminem „objawienie wewnętrzne”, które utożsamia z proponowaną filozofią. Rozumowanie Birana wydaje się przebiegać następująco: tak jak religia chrześcijańska objawia człowiekowi Boga w Osobie Jezusa Chrystusa, tak filozofia objawia człowiekowi samego siebie. Podczas gdy objawienie chrześcijańskie dociera do nas „z zewnątrz” to „objawienie rozumu” pochodzi „od wewnątrz”. Owo „objawienie wewnętrzne” jest osiągalne dzięki „wzmożonej refleksji” („réflexion concentrée”). Wtedy to właśnie człowiek zaczyna poznawać siebie od strony najważniejszej, a jest nią moralny aspekt jego człowieczeństwa. Wypełnia się wtedy program Sokratesa zawarty w jego powiedzeniu: ,poznaj samego siebie”. Proces poznawania i odkrywania wewnętrznego świata człowieka ciągle jeszcze trwa. Ten świat ciągle jeszcze czeka na swego „metafizycznego Kolumba” (J. I 176). Biran niewątpliwie sam pragnął zostać owym Kolumbem i dlatego tak uparcie studiował człowieka. W swoim ostatnim dziele, które skromnie określił: Nouveaux essais d'anthropologie, pisał „tyle już czasu upłynęło od chwili gdy zajmuję się studiowaniem człowieka albo raczej studiowaniem mojej własnej osoby" (O. XIV 202). Dlatego nasuwa się pytanie: czy Maine de Biran odkrył w końcu ten „nowy, wewnętrzny świat" człowieka?

\section{FILOZOFIA I RELIGIA NA PŁASZCZYŹNIE PRAKTYCZNEJ}

Powiedzmy to od razu, że Maine de Biran nie odkrył jakiegoś „nowego wewnętrznego świata”. Jednakże jego uparte „studium człowieka” nie poszło na marne. Przeciwnie, pozwoliło mu odkryć na nowo ważność odwiecznych ludzkich problemów i pytań, przed którymi staje każdy człowiek. I właśnie na tle tych problemów usiłuje on ustalić wzajemne relacje, jakie zachodzą pomiędzy filozofią a religią. Jakie to są problemy? Maine de Biran, jak zwykle, wyraża się językiem mało precyzyjnym, na co zwracał już uwagę Henri Gouhier ${ }^{4}$. Nie-

\footnotetext{
${ }^{4}$ Por. H. Go u h i e r, Les conversions de Maine de Biran, Paris 1948, s. 353.
} 
mniej jednak dokładna analiza wypowiedzi Birana pozwala ustalić, że miał on na myśli następujące zagadnienia:

a) problem sensu życia ludzkiego,

b) problem ludzkiego szczęścia,

c) problem śmierci człowieka.

Ad a) Maine de Biran stawia pytanie: „co będzie stanowić trwały punkt oparcia naszego istnienia? Do czego przyczepić naszą myśl aby mogła samą siebie odnaleźć?" (J. III 169). A w innym miejscu z jeszcze większym niepokojem zapytuje: , jestem już w podeszłym wieku, a ciągle jeszcze jestem niepewny i zmienny na drodze prawdy. Czy istnieje jakiś punkt oparcia i gdzie on jest?" (J. III 25). Innym razem bolesne pytania przechodzą w niemniej bolesne stwierdzenia: „największym nieszczęściem człowieka jest to gdy nie umie on ukierunkować swojego życia i nie wie jakiej trzymać się zasady" (J. II 280). I jeszcze jedno wyznanie: „człowiek, który ... nie umie nadać swemu życiu jakiegoś wielkiego celu, skazany jest na ustawiczną mękę" (J. II 279). We wszystkich tych sformułowaniach Maine de Birana przewija się jeden, podstawowy motyw na różny sposób wyrażany. Jest nim pytanie o sens swego życia a pośrednio o sens życia ludzkiego w ogóle. Dostrzec również można w tych zdaniach wielkie napięcie duchowe przypominające przeżycia w tym względzie samego Pascala. Biran szuka gwałtownie ostatecznego sensu swego życia. Broni się natomiast przed bezsensem, który nazywa „największą udręką ludzkiego ducha, prawdziwą trucizną życia" (J. II 280). Można w tym miejscu zrobić małe porównanie stanowiska Maine de Birana z tym, co w powyższej problematyce mówi współczesny, znany psychiatra i lekarz Victor Frankl. Twierdzi on, że w każdym człowieku istnieje bardzo silne pragnienie i wola sensu życia. Brak takiego sensu życia powoduje w czlowieku pustkę, frustrację egzystancjalną, które następnie

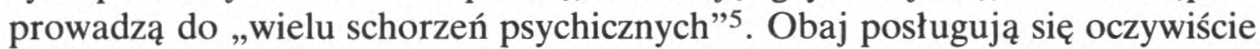
różnymi określeniami, by wyrazić rzecz, o którą im chodzi. Uwagi Maine de Birana okazują się jednak bardzo trafne w porównaniu z tym, co twierdzi Frankl. Gdy Biran zapytuje o „trwały punkt oparcia” naszego istnienia, to Frankl mówi o „woli sensu” naszej egzystencji. Gdy z kolei Frankl mówi o „frustracji egzystencjalnej" wynikającej z braku sensu życiowego, to Maine de Biran taki stan ducha nazywa "prawdziwą trucizną życia”.

Jaki zatem sens posiada ludzkie życie i gdzie szukać odpowiedzi na to pytanie? Filozofia nie da nam oczekiwanej odpowiedzi. Maine de Biran z naciskiem stwierdza: „tylko religia daje nam odpowiedź: filozofia nie jest w stanie tego uczynić" (J. III 169). Inaczej mówiąc, powstaje dość dziwna sytuacja: filozofia pozwala nam ujawnić zasadnicze dla człowieka pytanie, ale skutecznej odpowiedzi nam nie udzieli. Może to uczynić jedynie religia. Dlaczego jednak tak się dzieje, że filozofia jedynie stawia pytanie a dopiero religia daje na nie

${ }^{5}$ Por. V. E. Fr a n k 1, Paradoksy szczęścia, „Życie i Myśl” 1:1977, s. 40 nn. 
odpowiedź? Trudno jest znaleźć w dziełach de Birana jednoznaczną i całkiem jasną odpowiedź. Wróćmy jednak do pytania zasadniczego. Otóż opierając się na tekście zaczerpniętym z drugiego tomu jego Dziennika można odpowiedzieć następująco: życie ludzkie posiada pełny sens jedynie wtedy, gdy człowiek akceptuje istnienie Boga, gdy zwiąże się z tym „co jest zawsze takie samo, wieczne i niezmienne [...] czyli ostatecznie z Bogiem" (J. II 259). Maine de Biran chce powiedzieć, że człowiek przyjmując istnienie Boga odnajduje siebie, a odnajdując siebie znajduje sens swego życia. A z kolei o Bogu najpełniej poucza religia - w naszym przypadku religia objawiona.

Ad b). Biran szuka też odpowiedzi na pytanie, gdzie leży szczęście, owo „vrai contentement du couer”, jak je najczęściej określa. Rozwiązania szuka najpierw u filozofów. Nie znajduje go jednak u nich. Powołuje się na stoika, Marka Aureliusza, i pisze: „Marek Aureliusz wyraża się podobnie jak moraliści chrześcijańscy, że mianowicie, przechodząc przez poszczególne dobra zmysłowe nie podobna w żadnym $z$ nich znaleźć szczęścia: nie daje go ani wiedza, ani bogactwa, ani sława ani przyjemności” (J. III 176). Wypowiedzi „moralistów chrześcijańskich" de Biran nie przytacza. Wystarcza mu najzupełniej stwierdzenie Marka Aureliusza, że żadne dobro materialne nie jest w stanie dać człowiekowi poczucia szczęścia. Marek Aureliusz uważał jednak, że spełnianie przez człowieka czynów szlachetnych może człowiekowi przynieść szczęście. Biran przyznaje, że idea jest niewątpliwie piękna. Do pełnienia takich czynów trzeba mieć jednak odpowiednią siłę ducha. Dlatego zapytuje: „kto nam da potrzebną siłę do pełnienia takich czynów szlachetnych?" (J. III 177). Filozofowie jednak nie byli w stanie udzielić odpowiedzi na pytanie dotyczące szczęścia ludzkiego. Dlatego bez wahania stwierdza: „niestety filozofia jest tutaj bezradna, natomiast religia tryumfuje" (jw.). Zdaniem Maine de Birana religia tryumfuje, bo posiada sekret szczęścia ludzkiego. Tylko ona może udzielić odpowiedzi na to dręczące człowieka pytanie. Istotnie poucza nas religia, że „tylko posiadanie Boga [...] może stanowić trwałe szczęście człowieka” (J. II 259). Posiadanie Boga nie jest wszakże skutkiem tylko ludzkich zabiegów. Potrzebna jest człowiekowi pomoc łaski Bożej. Łaskę tę Bóg daje tym, którzy Go o nią proszą w duchu pokory: „doświadczenie poucza nas że prawdziwe szczęście nie zależy wyłącznie od woli: możemy je osiągnąć jedynie dzięki łasce Bożej, o którą należy prosić" (J. III 177). Religia nie tylko poucza człowieka, gdzie leży szczęście, ale daje mu również potrzebną pomoc, by je mógł osiągnąć. I na tym polega — zdaniem de Birana - wyższość religii w stosunku do filozofii.

Ad c). Dziennik Maine de Birana, zwłaszcza zaś okres ostatnich lat jego życia, jest świadectwem wewnętrznego zmagania się ze świadomością zbliżającej się śmierci. Dlaczego koniec? Dlaczego to życie musi się skończyć? Czy śmierć stanowi nieodwołalny koniec wszystkiego? Te i tym podobne pytania znaleźć można niemal na każdej stronie jego Dziennika. Drobiazgowo opisuje swój stan 
wewnętrzny, broni się przed nudą, zniechęceniem i rozpaczą. Sięga teraz coraz częściej do dostępnej mu literatury religijnej. Najchętniej czytuje dzieła Fénélona oraz Tomasza à Kempis: O naśladowaniu Chrystusa. Wyznaje: „religia jawi się przy końcu życia jako ogromne i jedyne źródło pociechy i siły moralnej" (J. II 160). Tym razem już nie próbuje porównywać filozofii i religii, nie usiłuje wykazywać wyższości religii nad filozofią. Mówi wprost: „tylko w religii można znaleźć pociechę i rekompensatę w tym stanie, każe nam ona widzieć koniec obecnego życia jako początek życia nowego, pouczając nas zarazem, że trzeba się wpierw ogołocić by ponownie się przyodziać" (J. II 323). Prawda ewangeliczna o ziarnie, które musi obumrzeć, aby następnie wydać owoc, przemawia do Maine de Birana najsilniej.

Jeżeli na płaszczyźnie teoretycznej (,dans les principes”) pomiędzy filozofią i religią istnieje swoista równowaga, to na płaszczyźnie praktycznej („dans l'application pratique") de Biran głosi wyższość religii w stosunku do filozofii. „Wyższość ta - stwierdza Biran - mniej dotyczy zasad ile raczej ich praktycznego stosowania" (J. III 177). Pewną trudność stanowić jednak może fakt, że Biran zalicza powyższe trzy problemy, tj. sens życia ludzkiego, problem szczęścia i śmierci człowieka, do sfery spraw praktycznych. Są to przecież z natury rzeczy zagadnienia wymagające od człowieka głębokiej refleksji a więc winny się znaleźć w dziedzinie spraw teoretycznych. Maine de Biran uważa jednak, że odpowiedź na pytanie o sens życia ludzkiego, o szczęście czy wreszcie problem śmierci człowieka to nie tylko przekazanie pewnej informacji, która ma zadowolić ludzki umysł. Odpowiedź taka to pomoc udzielona całemu człowiekowi a obejmująca tak ludzki umysł jak i całą sferę wolitywno-uczuciową czlowieka. Ponadto odpowiedź ta oznacza też działanie Boga przez łaskę i współdziałanie czlowieka przez modlitwę. $\mathrm{Z}$ tych więc względów - w opinii de Birana - powyższe trzy zagadnienia jak i odpowiedź na nie posiadają przede wszystkim charakter praktyczny. W tym znaczeniu pisał: „można uważać religię chrześcijańską za pewnego rodzaju system filozoficzny a sami się przekonamy, że nikt nam lepiej niż ona nie wyjaśni sprzeczności naszej natury; że zwłaszcza nie ma nic lepszego i bardziej wzniosłego w praktyce niż to co proponuje nam chrześcijaństwo" (J. II 352).

Koncepcja filozofii nie była oryginalnym osiągnięciem Maine de Birana. Sam przyznawał, że wzorował się na Sokratesie. Można również odnaleźć w jego filozofii motywy augustyńskie i pascalowskie, przynajmniej w interesującej nas sprawie. De Biran nie ukrywal, że „studium człowieka” — a na tym miała polegać proponowana przez niego filozofia - w pewnej mierze utożsa- 
miała się ze studium jego własnej osoby. Nie sądził jednak, by jego obserwacje $\mathrm{i}$ twierdzenia posiadały $\mathrm{z}$ tego podowu charakter wyłącznie sukiektywny. Uważał, że tą metodą odkrywa „prawdę o człowieku”, o każdym człowieku. Nawiązywał w tym niewątpliwie do rady św. Augustyna: „noli foras abire in teipsum redi: in interiore homine habitat veritas". Natomiast znaczenie i rola, jaką Biran przyznał religii objawionej w rozwiązywaniu najważniejszych dla człowieka problemów, wskazują wyraźnie na wpływ Pascala. To właśnie Pascal radził stawiać wiedzy wielkie wymagania i przekonać się następnie, że nie jest ona w stanie sprostać owym wymaganiom, by w końcu zawierzyć całkowicie religii. Wydaje się, że Maine de Biran zastosował ten właśnie scenariusz, gdy próbował ustalić relacje pomiędzy filozofią a religią. Co więcej, niekiedy dramatyczny ton wypowiedzi de Birana przypomina do złudzenia dramatyzm wypowiedzi Pascala. W swoich Myślach pyta Pascal: „Kto mnie tu postawił? Na czyj rozkaz i z czyjej woli przeznaczono mi to miejsce i ten czas? "Jakby echem tego pytania są słowa Maine de Birana z jego Dziennika: „Co będzie stanowić trwały punkt oparcia naszego istnienia?” Należy jednak przyznać, że Biran żył i tworzył w warunkach szczególnie trudnych. Są to czasy Wielkiej Rewolucji Francuskiej, której skutki we wszystkich dziedzinach życia długo jeszcze będą odczuwane we Francji. Swoją filozofię tworzył i głosił wtedy, gdy jeszcze dużo zwolenników posiadał Kartezjusz, kiedy znany był sensualizm Condillaca, a bardzo aktualny był Rousseau, nazwany przez niektórych historyków filozofii teoretykiem Rewolucji Francuskiej. Współcześni Birana oceniali jego filozofię jako czysty spirytualizm. Znany fizyk André Ampère przyjaciel de Birana, pisał: „Poświęcam zawsze dużo uwagi metafizyce i jestem mocno związany z Maine de Biranem. Jego dzieło, co dopiero nagrodzone przez Instytut i które ma być wnet opublikowane, jest dziełem zdecydowanie przeciwnym systemom nowoczesnym: jest to metafizyka całkowicie spirytualistyczna podobnie jak metafizyka Kanta, a może nawet jeszcze bardziej obca wszelkiemu materializmowi”6. Biran ze swoją koncepcją filozofii był wyraźnie osamotniony. Podobnie rzecz się ma z rolą, jaką wyznaczał Biran religii w rozwiązywaniu najważniejszych dla człowieka spraw. Wbrew ówczesnym tendencjom głosił on wartość i potrzebę religii objawionej w życiu człowieka a czynił to w okresie, gdy modnym był ateizm lub co najwyżej deizm.

$\mathrm{W}$ jednym wszakże punkcie jest zgodny $\mathrm{z}$ tendencjami swego czasu. Dla niego, jak i dla zwolenników oświecenia, w centrum uwagi jest człowiek. Obie strony jednak mają różną koncepcję człowieka. Zwolennicy oświecenia podkreślają absolutną autonomię człowieka we wszystkich dziedzinach. Jeśli zaś człowiek ma uznawać jakieś bóstwo, to tylko w ramach religii zgodnej z rozumem ludzkim za jaką uchodził wtedy deizm. Maine de Biran natomiast przez

${ }^{6} \mathrm{G}$. M a dini e r, Conscience et mouvement. Etude sur la philosophie française de Condillac à Bergson, Paris 1938, s. 178. 
swoje „studium człowieka” wykazuje, że ludzka egzystencja jest nie tylko niezrozumiała, ale wręcz tragiczna bez pomocy religii objawionej. Tutaj jednak pojawia się pewna trudność, na którą zwracają uwagę znawcy filozofii Birana. Jest to jego osobliwe i niepełne rozumienie religii objawionej. Henri Gouhier powołuje się na wypowiedź A.De La Valette-Monbrun, wedle której de Biran „był bardziej chrześcijaninem serca i uczucia niż doktryny”7. Od siebie zaś Gouhier dodaje, że Maine de Biran mial platońską wizję chrześcijaństwa, a gdy pod koniec swego życia usiłował przezwyciężyć platońskie ujęcie chrześcijaństwa „nie doszedł do kresu”. Kresem prawdziwego chrześcijaństwa jak zresztą i jego początkiem jest bowiem Jezus Chrystus, Ukrzyżowany i Zmartwychwstały Odkupiciel człowieka. Tymczasem Biran nie miał właściwego rozumienia roli Chrystusa jako Zbawiciela. Wprawdzie Biran uznaje, że Jezus Chrystus jest Zbawicielem ludzi, ale raczej jako ich wzór, niż ten, który ich rzeczywiście zbawil ${ }^{8}$. Jest to duży brak w poprawnym ujmowaniu chrześcijaństwa. Mając takie uproszczone rozumienie religii objawionej, Biran pozostał jednak do końca życia wierny swej tezie, że zasadniczych problemów człowieka nie rozwiąże się bez udziału tejże religii.

Biran sformułował swe stanowisko, o którego słuszności był osobiście głęboko przekonany. Wydaje się jednak, że jako takie zagadnienie stosunku filozofii do religii napotyka na trudności interpretacyjne. Wciąż nie jest jasne, jaka ostatecznie rola przypada filozofii, czy sprowadza się ona tylko do stawiania pytań, na które odpowiedź daje religia? Nawet przyjmując taką koncepcję filozofii, jaką proponuje Maine de Biran, tezy powyższej utrzymać się nie da. Filozofia nie tylko ma pytać, ale i udzielać odpowiedzi, oczywiście w ramach swoich możliwości i kompetencji. Sokrates - na którego powołuje się Biran - nie tylko szukał i stawiał pytania, ale też dawał na nie odpowiedź. I o tym Biran bardzo dobrze wiedział. Dlaczego więc nie podzielał do końca metody tego, do którego się odwoływal? A może Maine de Biran w omawianej kwestii chciał po prostu stwierdzić, że konsekwentne uprawianie filozofii jako „studium człowieka" prowadzi w sposób nieunikniony do wiary i religii? 


\section{PHILOSOPHIE ET RELIGION SELON MAINE DE BIRAN}

\section{Résumé}

Au commencement de cet article on a caraterisé la philosophie de Maine de Biran. Il parle tant de fois de Socrate qui a fondé la vraie philosophie. Cette philosophie a sa méthode propre qui est pratiquement la méthode d'intuition. L'objet spécifique de cette philosophie est „l'homme et la moralité” ou comme disait Biran „l'étude sur l'homme”.

S'il s'agit de la religion Maine de Biran pense toujours de la religion chrétienne. Les relations philosophie et religion Maine de Biran considère sur deux plans: théorique et pratique.

Sur le plan théorique: malgré la diversité fondamentale parmi la philosophie et la religion, elles coexistent harmonieusement. D'où vient cette harmonie? Premièrement elle vient de ce fait qu'elles ont une source commune, c.à.d. Dieu. Deuxièmement elles ont un rôle commun. Maine de Biran conçoit la philosophie comme une sorte de révélation. En ce cas la philosophie serait une révélation intérieure tandis que la religion serait un révélation extérieure. Toutes les deux doivent révéler quelque chose. La religion révèle Dieu a l'homme et la philosophie révèle à l'homme sa propre nature, ses problèmes fondamentaux, en un mot révèle l'homme à lui-même.

Sur le plan pratique la philosophie conçue comme une révélation révèle vraiment à l'homme trois grands problèmes de la vie humaine: le sens de la vie humaine, le problème de bonheur de l'homme et le problème de la mort humaine. A ces grands problèmes l'homme doit chercher une réponse. Mais la philosophie ne peut pas donner cette reponse, ici „elle est en defaut” - comme dit exactement Maine de Biran. Seulement la religion peut donner la réponse suffisante. C'est pourquoi Maine de Biran parle de „supériorité de la religion”. A la fin de sa vie et de ses „études sur l'homme" il confesse: „La religion resout seule les problèmes que la philosophie pose”. 